\title{
Service de placement
}
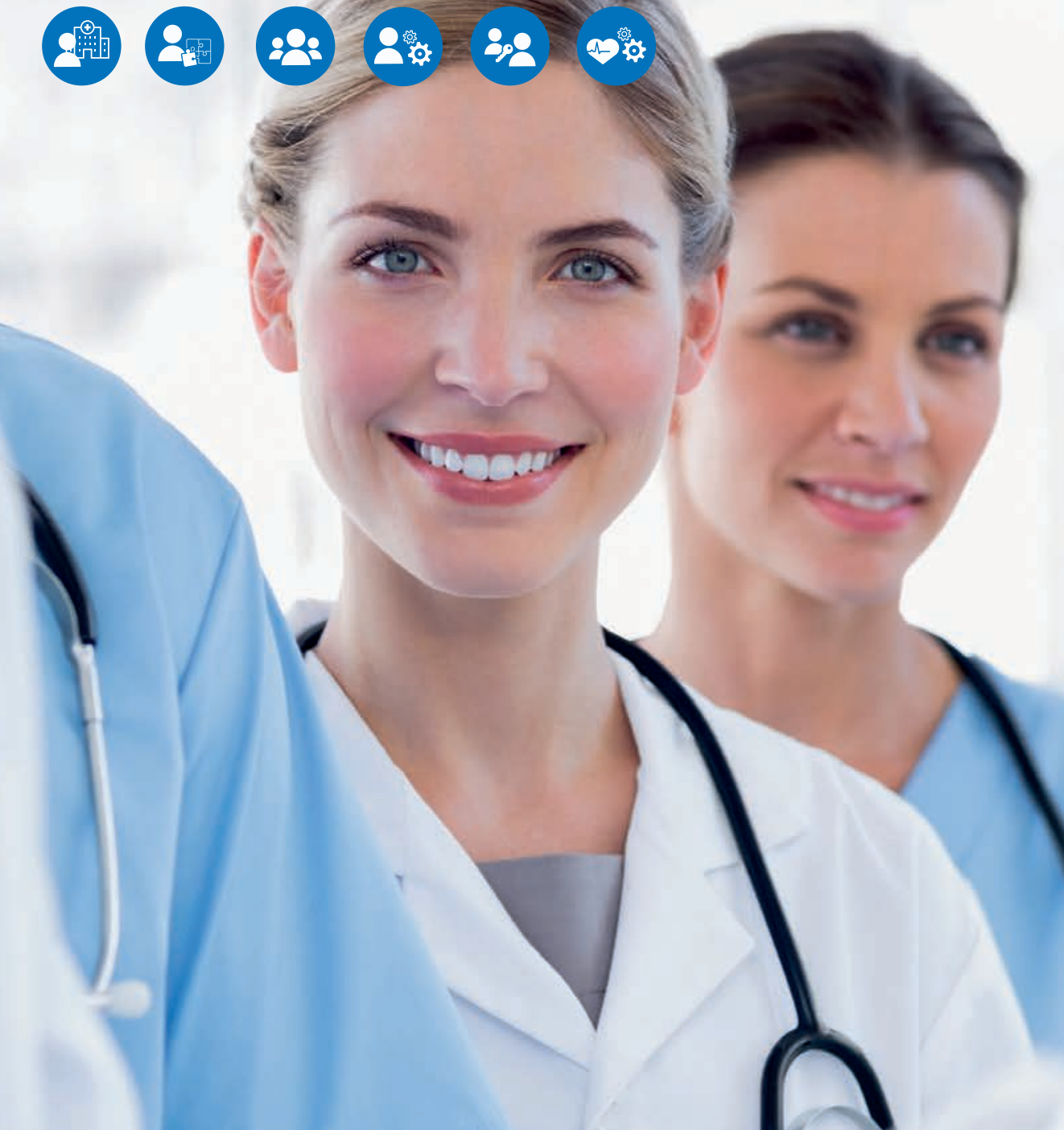